\title{
ASSESSMENT OF SUSCEPTIBILITY TO DEGRADATION BY SCHINDLER FACTOR OF SELECTED RESERVOIRS IN PODLASKIE - PART I
}

\author{
Ewa Szatyłowicz' . Dominika Matulewicz', Iwona Skoczko'
}

1 Bialystok University of Technology, Wiejska St. 45, 15-351 Białystok, Poland, e-mail: e.szatylowicz@doktoranci. pb.edu.pl; d.matulewicz@doktoranci.pb.edu.pl; i.skoczko@pb.edu.pl

Received: 2015.06 .22

Accepted: 2015.08.31

Published: 2015.10.01

\begin{abstract}
The availability of water in adequate sufficient quantity and quality is the most important factor in maintenance of life and human activity. Surface water as easily accessible resources per citizen in Poland should not be compared to other countries of the European Union. Podlasie is a lowland region, which is dominated by vast plains occasionally varied by low hills with gentle slopes. Natural lakes occurring sparsely are heavily overgrown or completely restated as a result of moor succession. The storage of natural hollows which store water resulted in the construction of artificial dam reservoirs, allocated primarily to water accumulation. Lowland development of small retention mainly consists of increasing the retention capacity and prevention of drought and floods, while maintaining and supporting the development of the natural landscape. This article presents the characteristics of selected major small water reservoirs in Podlasie. Characterized and evaluated the susceptibility of dam reservoirs degradation: Czapielówka, Korycin, Otapy-Kiersnówek, Repczyce, Zarzeczany. To evaluate the susceptibility of degradation there was applied Schindler factor, which is the ratio of the accumulated surface water reservoir and its catchment area to the volume of the reservoir. In addition, the influence of development of catchment management and the degree of degradation has been evaluated. Realising aware of the limitations of the size of the water resources is suggested to take appropriate action to alleviate the degradation of artificial reservoirs.
\end{abstract}

Keywords: water resources, Schindler factor, low retention, degradation.

\section{INTRODUCTION}

Increase of water resources in lowland areas of Podlasie occurs by sustainable modes of water retention in a form of small retention. Methods included to the natural forms, consists of restoration of the original terms of the aquatic environment, for example, increase of the forest cover or restoration of natural conditions in former wetland environments. Artificial methods include all kinds of hydraulic structures, like large reservoirs and small river dams [Michalak, Nowicki 2009]. Small dam reservoirs are a specific type of an artificial lake, which is susceptible to retention of nutrients, this results in an increase in sensitivity of ecosystems and accelerates eutrophication processes. The specificity of their functioning con- sists of continuous transport of various forms of matter from the catchment and its accumulation in the reservoir. They become sedimentation traps for pollution supplied by river. The consequence of this process is partial or complete loss of usability. More than 20 artificial reservoirs are built in Podlasie. Most of these waters occurred by the development of small retention program. The quality of water in small reservoirs is affected by changes in flowing surface water. Many factors affect the size of the flowing nutrients load into the reservoirs. The most significant influencing factors include: catchment management, the size and reduce of the surface area, the type and degree of soil cover vegetation, population density, sanitation, the level and method of fertilization [Giercuszkiewicz-Bajtlik 1990; Ilnicki 2002]. 
The problem of degradation of water reservoirs is their progressive eutrophication, mainly due to the excessive load of the lake and carried from the biogenic organic matter. The whole change causes elimination of water resources [Bańkowska, Sikora 2014]. Limitation of external sources which carry significant loads of pollution, does not give the end of the possible solutions to the problem of deepening degradation. Stagnant water has less facility to self-cleaning. This is caused by reduction possibility of oxygen replenishment or lack of exchange in case of outflow-less reservoirs. This results in the occurrence of intense development of aquatic organisms, which die and then sediment on the bottom and decompose. Aerobic conditions contribute to the formation of mineral sediments of biogenic substances during their degradation. In anaerobic conditions phosphorus and nitrogen is released from sludge. Then, it returns to the matter circulation in the water reservoir ecosystem. This results in increased growth of sludge, which leads to overgrowing and shallowing of water reservoirs. Consequently this causes water reservoir atrophy [Kowalewski 2009; Kowalewski 2012].

Small retention objects are designed to prolong the water circulation. However, the impact of a single water reservoir on the flows and water resources is small, but with a large number of dams it can be significant. The construction of many small reservoirs only to improve the water balance is usually unprofitable, because these objects perform a variety of functions: economic, recreational and natural. These reservoirs mostly contribute to the attractiveness of the surrounding area [Mioduszewski 2006].

Evaluation of natural susceptibility to degradation mainly caused by anthropopressure may be based on the basis of the Schindler ratio, which reflects the influence of the on reservoir. It has been proved that there is correlation between the value of this index, and the value of the parameters relating to the status of water quality [Schindler 1971; Miazga 2013]. This indicator considers the surface area of the direct catchment, which defines topography. The volume, which was also included in the Schindler factor, indirectly takes account into the given water reservoir depth.

\section{MATERIALS AND METHODS}

In order to assess the susceptibility to degradation of individual reservoirs was used
Schindler factor, which is ratio determining parameter of the accumulated surface water reservoir and its catchment area to the volume of the reservoir [Koc et al. 1996]. Used indicator is a measure of the impact of the environment on the reservoir. With an increase of Schindler factor, the pollution of the water reservoir also rises. Lakes or reservoirs with ratio value less or equal to 2 are treated as not susceptible to degradation due to the inflow of pollutants from the catchment [Szoszka et al. 2007]. Schindler's threshold score amounting 2 is also criterion taken into account when assessing water quality. To evaluate reservoirs, Schindler factor may be applied, because like a lake, including the catchment area they are natural landscape system, in which there is a constant flow of matter and energy. Degradation susceptibility of such a system depends on the pressure which the catchment exerts on water reservoir and on the resistance to this pressure [Kostrzewski 1991]. For the calculation of the Schindler factor used is formula (1) [Kajak 1998].

$$
W S=\frac{P z l+P z}{V j}\left[\mathrm{~m}^{-1}\right]
$$

where: $P_{z l}$ - the catchment area of the water reservoir;

$P_{z}-$ the surface of the water reservoir;

$V_{j}^{z}$ - the volume of the water reservoir.

Reservoirs volume were obtained on the basis of the technical documentation of the individual objects. Individual catchments and reservoirs were determined using a topographic map from www.geoportal.gov.pl with marked levels. This web is primarily a set of tools providing access to data and documents PZGiK and it also contains the data and metadata in accordance with the requirements of the INSPIRE Directive. On the map is located the bounded area by the local terrain elevations, which are natural catchment boundary for small water objects. Secondly they were combined together by using the "measure the surface" - located on the www.geoportal.gov. pl system, calculated catchment area with the surface of the reservoir.

In addition, using plans and data from community administration offices, where are located various reservoirs, catchment management was estimated. Considering the hydromorphological features of water reservoir assessed susceptibility to degradation. 


\section{Czapielówka reservoir}

Czapielówka is a small retention reservoir which is located in a forest in the urban-rural community of Czarna Białostocka, surrounded by Knyszyńska Forest. It was built between 1971 -1981 as a result of damming the river bed earthen in the 7 kilometer Czapielówka river [Szczykowska, Siemieniuk 2011]. Basic technical parameters of the reservoir Czapielówka are given below in Table 1.

In addition to the recreation flow reservoir performs many other functions, which can include: objectives of flood, fire and extensive fish farming, environmental protection [Kudelska et al. 1994]. In Figure 1 outlined catchment of the reservoir Czapielówka and its surface was determined in hectares using the Geoportal.

Calculated area amounted to 467.71 ha or $4677100 \mathrm{~m}^{2}$. Schindler factor was 14.76 (model 2).

$$
W S=\frac{4677100}{316955}=14.76\left[\mathrm{~m}^{-1}\right]
$$

Czapielówka reservoir catchment areas are occupied by pine forests, classified as complex

Table 1. Technical parameters of the reservoir Czapielówka [Szczykowska, Siemieniuk 2011]

\begin{tabular}{|l|c|c|}
\hline \multicolumn{1}{|c|}{ Parameter } & Unit & Value \\
\hline Water surface area & ha & 16.5 \\
\hline Width & $\mathrm{m}$ & 570 \\
\hline Length & $\mathrm{m}$ & 800 \\
\hline The average depth & $\mathrm{m}$ & 2.00 \\
\hline Maximum depth & $\mathrm{m}$ & 3.00 \\
\hline Volume & thus. $\mathrm{m}^{3}$ & 316955 \\
\hline
\end{tabular}

of Forest Knyszyńska, wastelands, meadows and pastures. Pine forests occur on poor and extremely poor soils, acidic, produced from tar sands, loose or poorly clay, but also peatland. Forest cover at Czapielówka reservoir catchment is about $75 \%$ of the area [Szczykowska, Siemieniuk 2011]. Typically, forest catchment causes a flow of humic acids, characterized by high concentrations of dissolved organic carbon. This results in increased colour, turbidity, organic matter in the water of reservoir [Klimaszczyk, Joniak 2008].

\section{Korycin reservoir}

The Korycin water reservoir was built in September 2002 on the Kumiałka River. It's located in the Sokółka District. Table 2 presents the characteristics of Korycin reservoir.

Reservoir was built for the recreational and sporting use, also acts as a retention and flood reservoir [Szczykowska et al. 2013; Unpublished documents from Gmina Korycin].

Table 2. Technical specifications characterizing the reservoir Korycin [Szczykowska et al. 2013; Unpublished documents from Gmina Korycin]

\begin{tabular}{|l|c|c|}
\hline \multicolumn{1}{|c|}{ Parameter } & Unit & Value \\
\hline Year of construction & year & 2002 \\
\hline Length & $\mathrm{m}$ & 440 \\
\hline Width & $\mathrm{m}$ & 145 \\
\hline Water surface area & ha & 6.8 \\
\hline Volume & thous. $\mathrm{m}^{3}$ & 81 \\
\hline The average depth & $\mathrm{m}$ & 1.65 \\
\hline Length of coastline & $\mathrm{m}$ & 1000 \\
\hline
\end{tabular}

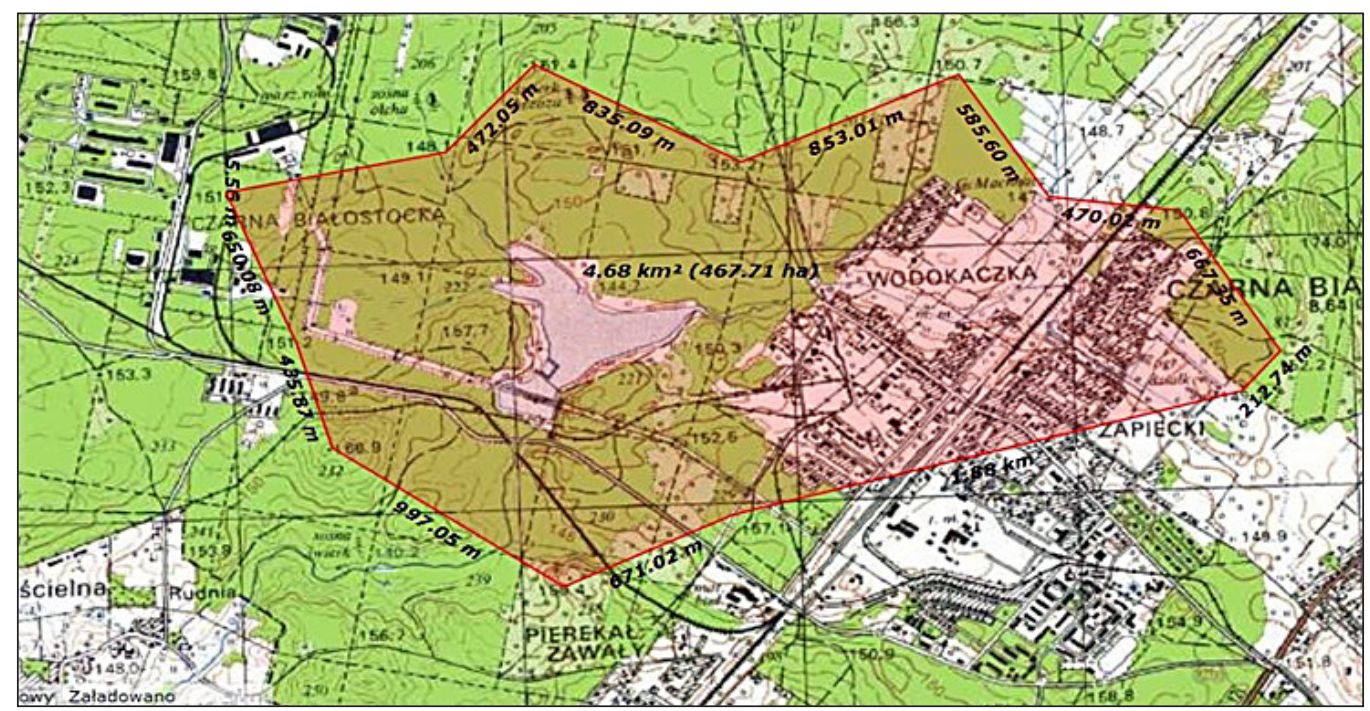

Figure 1. Designated catchment of the reservoir Czapielówka [www.geoportal.gov.pl] 
The largest reservoir catchment area in terms of typological occupy brown soils, pseudo-podzolic soils, black soils and alluvial soils in river valleys. The $84.9 \%$ is dominated by agricultural land. This contributes to runoff from the catchment area of pollution characterized by a much higher content of nitrogen and phosphorus [Chełmicki 2002].

Calculated area amounted to 359.24 ha or $3592400 \mathrm{~m}^{2}$. Schindler factor was calculated, was according to 44.4 (model 3 ).

$$
W S=\frac{3592400}{81000}=44.4\left[\mathrm{~m}^{-1}\right]
$$

\section{Otapy-Kiersnówek reservoir}

The water reservoir Otapy-Kiersnówek was built in 2008. It is situated in the picturesque valley of the Nurzec River in reducing field on the right bank of the river, in the village Kiersnówek, in the municipality Brańsk. It satisfies the a very important task-water storage reservoirs and rivers that are fed inlet structure and in addition is intended for recreational purposes, such as water sports and fishing. The ability of water retention in the reservoir of flood wave flattens, reduce the uncontrolled flooding of water in the valley [Un-

Table 3. Technical characteristics the reservoir OtapyKiersnówek [Unpublished documents from Gmina Brańsk]

\begin{tabular}{|l|c|c|}
\hline \multicolumn{1}{|c|}{ Parameter } & Unit & Value \\
\hline Year of construction & year & 2008 \\
\hline Length & $\mathrm{m}$ & 750 \\
\hline Water surface area & ha & 4.8 \\
\hline Volume & thous. $\mathrm{m}^{3}$ & 62 \\
\hline Normal levels of damming & m n.p.m. & 127.4 \\
\hline The average depth & $\mathrm{m}$ & 1.6 \\
\hline
\end{tabular}

published documents from Gmina Brańsk]. Table 3 presents the characteristics of the water reservoir Otapy-Kiersnówek.

Land is occupied by the construction of small retention reservoir Otapy-Kiersnówek accounted for pastures class $\mathrm{V}$ and a small agricultural area class III and IV. The reservoir was built in lowered area adjacent directly into the river Nurzec, fenced off from of the river bed causeway side. In the valley of the river Nurzec are mainly silt layers deposited by water during the floods of the river and on a small area of peat and muck-peat soils. Brańsk is typically agricultural commune as it is located in a favorable as the terms of the Podlaskie region, climate zone, while having a good state of the environment [Szczykowska et al. 2013; Unpublished documents from Gmina Brańsk]. Agricultural catchment management will increase the content of nitrogen and phosphorus [Chełmicki 2002].

In Figure 3 shows the designated catchment reservoir Otapy-Kiersnówek, which amounted to 271.36 ha or $2713600 \mathrm{~m}^{2}$. Then calculated Schindler factor, which amounted to 43.7 (model 4).

$$
W S=\frac{2713600}{62000}=43.7\left[\mathrm{~m}^{-1}\right]
$$

\section{Repczyce reservoir}

The Repczyce reservoir was built in 20012002 on the Nurzec River, which is a right tributary of the Bug Rivier and the source in a short distance from the reservoir in the village of Stawiszcze. The reservoir is located in the Repczyce village, which is located in Kleszczele municipality, Hajnówka District. Figure 4. presents geographic location of the reservoir along with the designated catchment area.

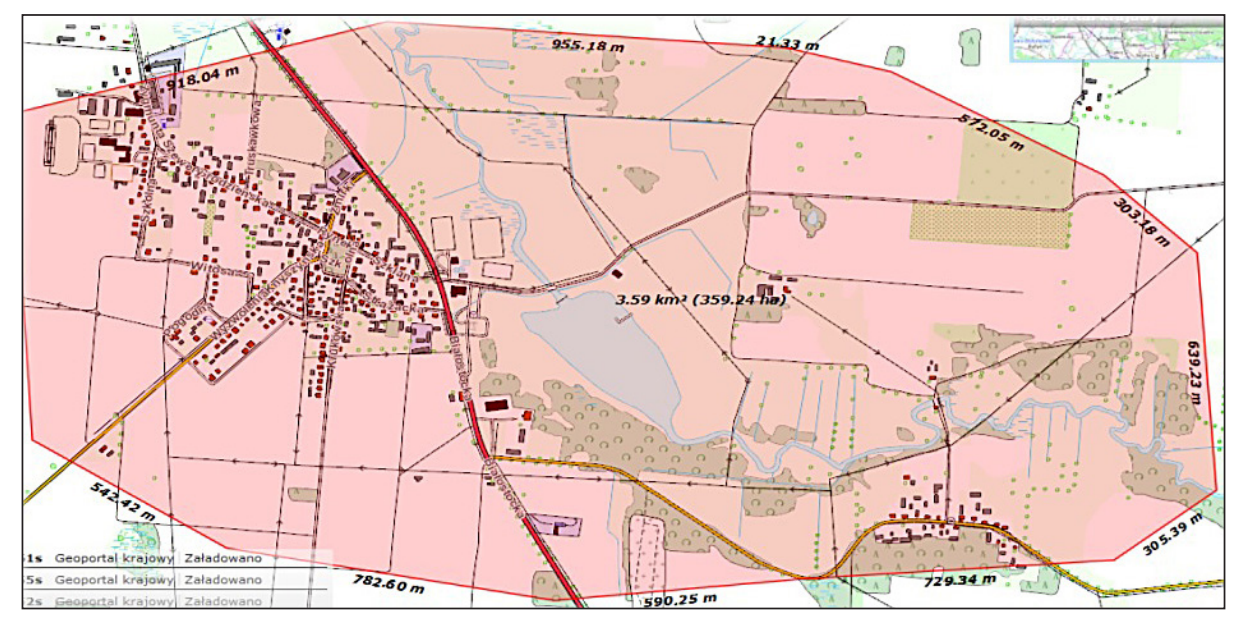

Figure 2. Designated catchment reservoir Korycin [www.goeportal.gov.pl] 


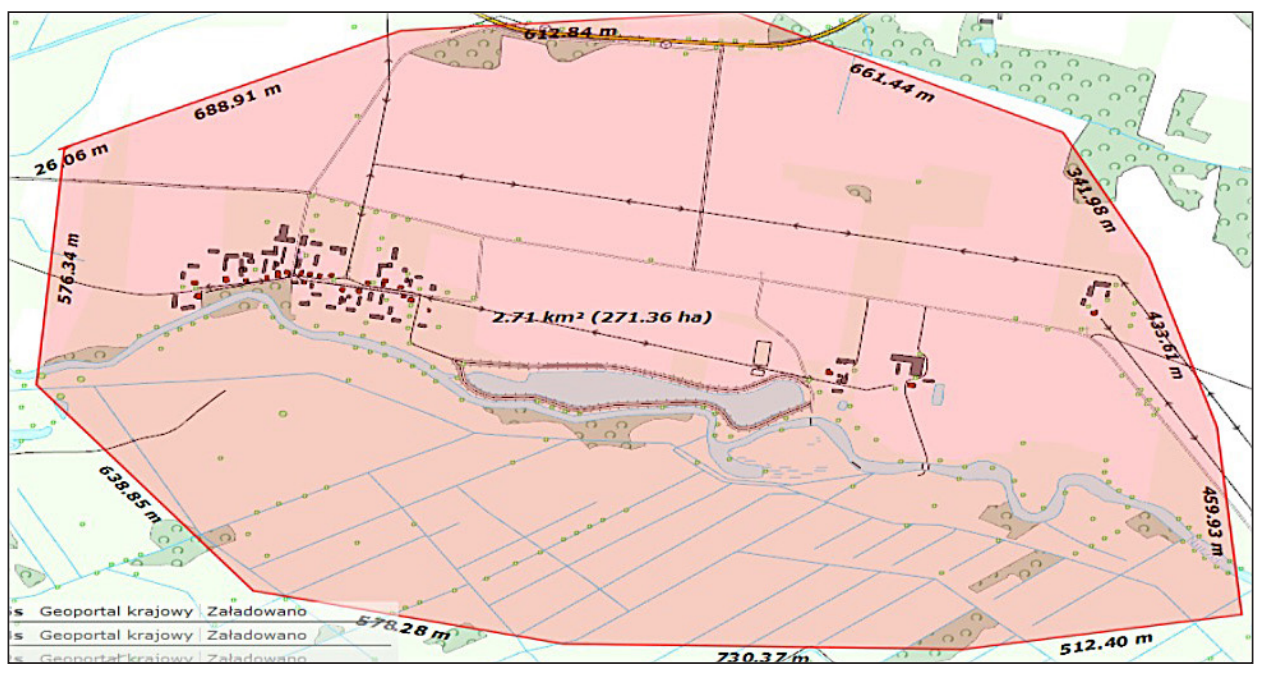

Figure 3. Designated catchment reservoir Otapy-Kiersnówek [www.geoportal.gov.pl]

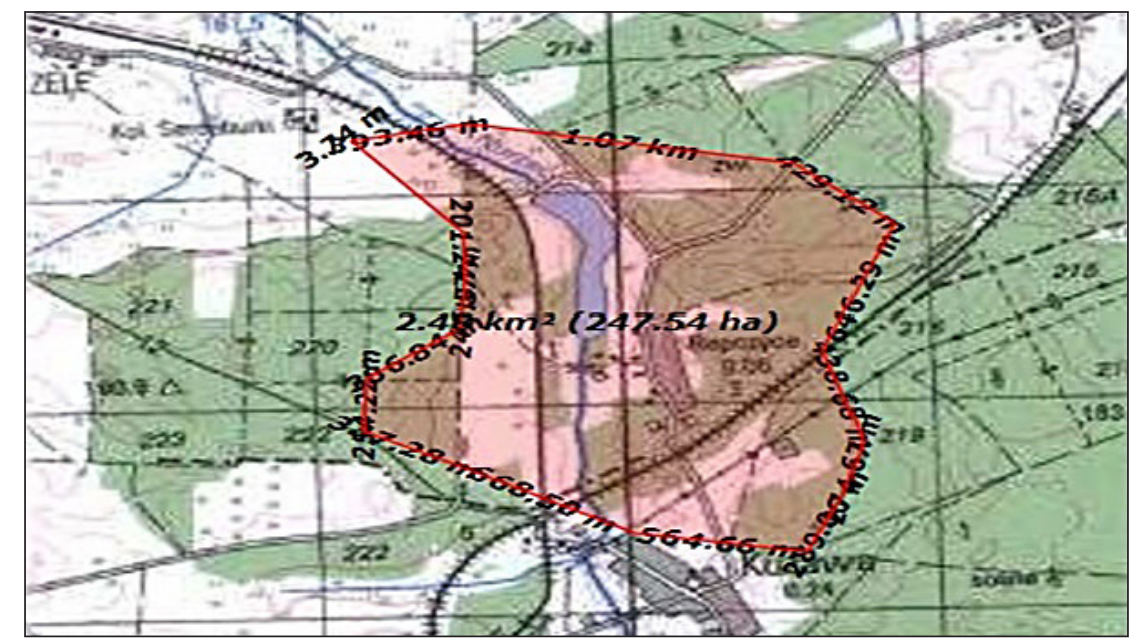

Figure 4. Designated catchment of Repczyce reservoir [www.geoportal.gov.pl]

The reservoir collects surface waters of the top of the drainage area of the Nurzec River. The areas adjacent to the river are mainly glacial sands with no large patches of clay. In addition to the wet valleys flowing rivers are peats of different thickness [Unpublished documents from Gmina Kleszczele]. The character of the catchment development Repczyce reservoir can be defined as agro-forestry, because Nurzec River and its tributaries create a water system, which drains water from the grassland from the Czeremcha community [Unpublished documents from Gmina Kleszczele]. The mixed nature of the catchment management is characterized by containing compounds runoff as nutrients and organic matter, mainly humic acids resulting in elevated levels of organic carbon [Chełmicki 2002, Klimaszczyk, Joniak 2008]. Table 4 presents technical parameters of Repczyce reservoir.
On the basis of figure 4 . and the data from table 2.8. Schindler factor was 12.05 (model 5).

$$
W S=\frac{2475400}{205460}=12.05\left[\mathrm{~m}^{-1}\right]
$$

Table 4. Technical characteristics Repczyce reservoir [Unpublished documents from Gmina Kleszczele]

\begin{tabular}{|l|c|c|}
\hline \multicolumn{1}{|c|}{ Parameter } & Unit & Value \\
\hline Year of construction & year & $2001-2002$ \\
\hline Water surface area & ha & 10.36 \\
\hline Volume & thous. $\mathrm{m}^{3}$ & 205.46 \\
\hline Length of coastline & $\mathrm{m}$ & 2060 \\
\hline Length & $\mathrm{m}$ & 774 \\
\hline Width & $\mathrm{m}$ & 134 \\
\hline Normal levels of damming & $\mathrm{m}$ n.p.m. & 167.5 \\
\hline $\begin{array}{l}\text { The maximum level of } \\
\text { damming }\end{array}$ & $\mathrm{m}$ n.p.m. & 167.9 \\
\hline The average depth & $\mathrm{m}$ & 1.98 \\
\hline $\begin{array}{l}\text { The maximum depth of } \\
\text { reservoir at the dam }\end{array}$ & $\mathrm{m}$ & 3.05 \\
\hline
\end{tabular}




\section{Zarzeczany reservoir}

Zarzeczany water reservoir was built and opened for use in 2000 in the village of Zarzeczany. It is one of region's places of interest and attracts Polish and foreign vacationers to Gródek. Table 5 shows its technical specifications.

Zarzeczany small retention reservoir is located in district of Białystok in agricultural area on slightly undulating terrain. The catchment area is comprised mostly of grasslands with significant part of woodlands at its periphery, that is at the edge of Puszcza Knyszyńska [Grygorczuk-Petersons 2008] Pollutants carried by runoff water are characterized by increased content of organic compounds and mineral forms of nitrogen and phosphorus [Klimaszczyk Joniak 2008; Klimaszczyk, Rzymski 2011]. Based on Figure 5 using Geoportal surface of catchment area was calculated to be 356.53 ha $\left(3265300 \mathrm{~m}^{2}\right)$. Subsequently calculated Schindler's Factor amounted to 42.4 (formula 6).

$$
W S=\frac{3265300}{77000}=42.4\left[\mathrm{~m}^{-1}\right]
$$

Table 5. Characteristics of Zarzeczany reservoir [Grygorczuk-Petersons 2008]

\begin{tabular}{|l|c|c|}
\hline \multicolumn{1}{|c|}{ Parameter } & Unit & Value \\
\hline Year of construction & year & 2000 \\
\hline Surface area & ha & 8.75 \\
\hline Volume & thousand $\mathrm{m}^{3}$ & 77 \\
\hline Avg. depth & $\mathrm{m}$ & 1.92 \\
\hline Maximum depth & $\mathrm{m}$ & 3.1 \\
\hline
\end{tabular}

\section{RESULTS AND DISCUSSION}

Following table shows the results of conducted analyses and calculations (Table 6).

The higher the Schindler's Factor the greater impact environment has on reservoir's pollution and degradation. Lakes and reservoirs with Schindler's Factor not greater than 2 are considered as slightly susceptible to degradation under the influence of polluted surface runoff [Szoszka et al. 2007].

Average depth of water body is the most important morphometric parameter associated with water quality and the rate of its overgrowing. Deeper reservoirs are able to fully circulate water during spring and autumn circulation which greatly impacts the quality of water. Artificial small retention reservoirs depth ranges from 1 to 4 meters. The deeper the reservoir is, the greater stratification of water allowing formation of particular zones, in which different transformation processes of compounds inflowing into reservoir. Natural lakes' average depth often ranges form

Table 6. Schindler's Factor's values

\begin{tabular}{|c|l|c|c|}
\hline No. & Water reservoir & $\begin{array}{c}\text { Schindler's } \\
\text { Factor }\left[\mathrm{m}^{-1}\right]\end{array}$ & $\begin{array}{c}\text { Nature of } \\
\text { catchment area }\end{array}$ \\
\hline 1 & Czapielówka & 14.76 & woodland \\
\hline 2 & Korycin & 44.4 & agricultural \\
\hline 3 & Otapy - Kiersnówek & 43.7 & agricultural \\
\hline 4 & Repczyce & 12.05 & $\begin{array}{c}\text { agricultural- } \\
\text { woodland }\end{array}$ \\
\hline 5 & Zarzeczany & 42.4 & $\begin{array}{c}\text { agricultural- } \\
\text { woodland }\end{array}$ \\
\hline
\end{tabular}

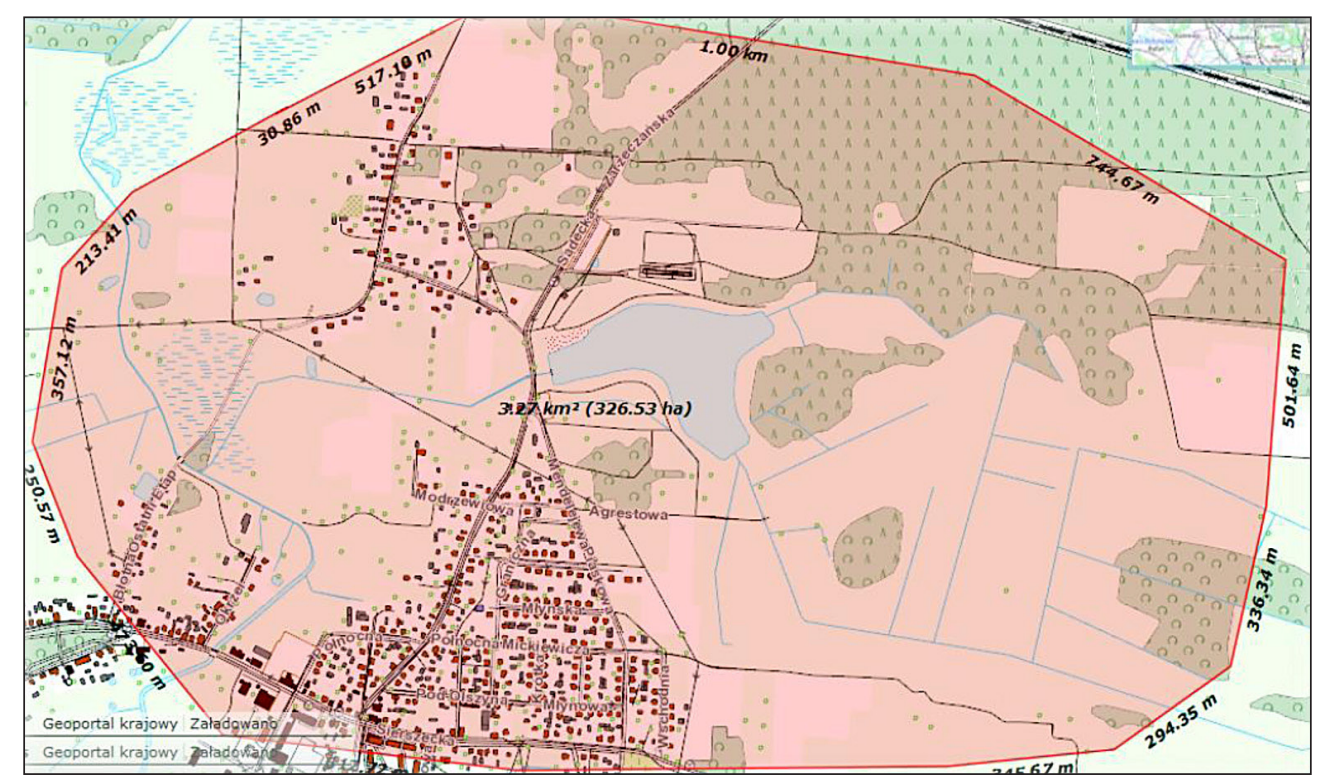

Figure 5. Outlined catchment area of Zarzeczny reservoir [www.geoportal.gov.pl] 
10 to 15 meters which allows formation of these zones and reduces vulnerability to eutrophication. Such a relationship was observed by Waldemar Siuda and Tomasz Kaliński who conducted research on eutrophication of southern part of the Great Lakes of Masuria [Siuda, Kaliński 2011].

Water quality in artificial lakes depends, to a large extend, on how the adjacent lands, from which runoff occurs, are used. Determining the land use directly within catchment area the most important part is the forest area beneficial to the protection of water reservoirs. Large area of arable land is a potential source of biogenics, which can contribute to lowering water quality and increase its susceptibility to degradation. Unfortunately, we need to pay special attention to anthropogenic eutrophication taking place in artificial lakes. Most of the artificial lakes are designed for comprehensive utilization, mainly storing water they serve multiple other functions as well. Fertilizing processes occurring therein can create many technological and sanitary-epidemiological difficulties during water treatment. Artificial water reservoirs are located in most part in regions with high population densities, what increases the influence of their anthropological impact. Water quality in artificial reservoirs deteriorates most in early years of their functioning. Submersion in Kraśnik is an example, in which fast eutrophication indications were found. Manifestation of that fact was the appearance of cyanobacterial blooms in the summer, including potentially toxic Aphanizomenon flos-aquae in 2 years since the reservoir was filled with water. This contributed to the closure of swimming place functioning there [Pęczuła, Suchora 2011]. Elution of chemicals from flooded lands increases productivity and leads to intensive development of phytoplankton [Neverova-Dziopak et al. 2011]. An example of a progressive degradation of an artificial water reservoir can be the artificial Zemborzycki Lake, in which advanced trophic state as well as shallowing by the indigenous organic matter sedimenting to the bottom of the lake, were observed just a few years after its construction. Additionally, the reservoir is characterized by a small biocenotic variation and it is dominated by phytocoenoses typical to eutrophic and degraded waters [Kułak et al. 2010]. Artificial water reservoirs differ significantly from natural lakes, some of the methods used for assessing susceptibility to degradation of lakes can be used for the assessment of artificial reservoirs. Schindler's Factor does not account for land use in the catchment area, which plays a significant part in shaping susceptibility to degradation. Unique system or comprehensive index combining hydromorphologic and geologic parameters of reservoir that takes into account nature of land use around the reservoir should be developed in the future.

\section{CONCLUSIONS}

1. All of the examined reservoirs are used mainly as water storage, but serve multiple other functions as well i.e.: recreational, flood control, fire protection, and economic.

2. The analysed small retention reservoirs, irrespectively to the nature of catchment area land use, are to a large extent susceptible to degrading because their hydromorphological parameters differ from natural lakes.

3. Low depth of artificial reservoirs contributes to the increase in the degradation rate.

4. Due to utilization of the catchment area, unfavourable hydromorphological parameters of artificial lakes, in comparison to the natural ones, aimed at improving water quality should be used, which in turn at a later stage will reduce their susceptibility to degradation.

\section{REFERENCES}

1. Michalak J., Nowicki Z. 2009. Designation of changes in groundwater resources in the areas of small water reservoirs. State information service hydrogeological, Państwowy Instytut Geologiczny, Warszawa (in Polish).

2. Giercuszkiewicz-Bajtlik M. 1990. Prediction of changes in the quality of stagnant water. Wydawnictwa Instytutu Ochrony Środowiska, Warszawa (in Polish).

3. Ilnicki P. 2002. The causes, sources and course eutrophication of surface waters. Przegląd Komunalny, 2, 125, 35-49 (in Polish).

4. Mioduszewski W. 2006. Small water reservoirs. Wydawnictwo IMUZ. Falenty (in Polish).

5. Koc J., Ciećko C., Janicka R., Rochwerger A. 1996. Factors determining mineral forms of nitrogen in the waters of agricultural areas. Zeszyty Problemowe Postępów Nauk Rolniczych, 440, 175-183 (in Polish).

6. Szoszka H., Kolada A., Gołub M., Cydzik M. 2007. The Water Framework Directive in Poland - typology 
of lakes, establishing reference conditions, methods of assessment and classification on the basis of biological elements - Part 2. 20 March, p. 5 (in Polish).

7. Kostrzewski A. 1991. The concept of the program: monitoring the circulation of matter, comprehensive monitoring of the natural environment in basic types geoecosystems of Poland. Komitet Naukowy przy Prezydium PAN „Człowiek i Środowisko”, Poznań (in Polish).

8. Kajak Z. 1998. Hydrobiology - Limnology of inland water ecosystems. Wydawnictwo PWN, Warszawa (in Polish)

9. Bańkowska A., Sikora A. 2014. A compendium of knowledge - aquatic ecosystems. http://h2o.zrodla. org/materialy/ (02.12.2014) (in Polish).

10. Unpublished documents from Gmina Brańsk (in Polish).

11. Szczykowska J., Siemieniuk A., Wiater J. 2013. Ecological problems of small water reservoirs in Podlasie. Ekonomia i Środowisko, 4, 234-244.

12. Unpublished documents from Gmina Korycin (in Polish).

13. Grygorczuk-Petersons E. 2008. The influence of precipitation on the water body of water Zarzeczany Podlaskie voivodship. Polska Akademia Nauk, Oddział w Krakowie. Infrastruktura i Ekologia Terenów Wiejskich, no. 5, 129-137 (in Polish).

14. Chełmicki W. 2002. Water: resources, degradation, protection. PWN, Warszawa (in Polish).

15. Szczykowska J., Siemieniuk A. 2011. Formation of concentrations of nutrients in the waters of the reservoir Czapielówka. Ochrona Środowiska i Zasobów Naturalnych no. 48, 324-333 (in Polish).

16. Kudelska, D., Cydzik, D., Szoszka, H. 1994. WThe guidelines basic monitoring of lakes. Biblioteka Monitoringu Środowiska, Warszawa (in Polish).

17. Unpublished documents from Gmina Kleszczele (in Polish).

18. Schindler D.W. 1971. A hypothesis to explain differences and similarities among lakes in experimental Lake area Northwestern Ontario. J. Fish. Res. Board Canada, 285-301.
19. Miazga M. 2013. Evaluation of natural susceptibility of degradation and water quality of the reservoir Wapienica. Acta Geographica Silesiana, Sosnowiec 13, 43-49 (in Polish).

20. Kułak A., Maślanko W., Sender J. 2010. The impact of the direct catchment management on the development of aquatic vegetation Zemborzycki Lagoon, Multidirectionality research in agriculture and forestry: Monograph, Vol. 1. Wydawnictwo Uniwersytetu Rolniczego, Kraków, 355-361 (in Polish).

21. Siuda W., Kaliński T. 2012. Eutrophication southern part of the Great Mazury Lakes in the years 19772011 the causes, mechanisms and consequences. Zakład Ekologii Mikroorganizmów UW (in Polish).

22. Neverova-Dziopak E., Kowalczyk E., Bartoszek L., Koszelnik P. 2011. Assessment of trophic status of the dam reservoir Solina, Zeszyty Naukowe Politechniki Rzeszowskiej, 276, 197-208 (in Polish).

23. Kowalewski Z. 2009. Methods of assessment trophic status of surface waters. Materiały Krakowskiej Konferencji Młodych Uczonych, Kraków, 17-19 września (in Polish).

24. Kowalewski Z. 2012. Verification possibility of using the integral criterion to assess the trophic status of rivers. The doctoral thesis AGH, Kraków, winntbg.bg.agh.edu.pl/rozprawy2/10509/full10509. pdf (28.11.2014) (in Polish).

25. Pęczuła W., Suchora M., 2011. Analysis of the causes of poor water quality in the storage reservoir in Kraśnik in the first years of its operation. Przegląd Naukowy - Inżynieria i Kształtowanie Środowiska, 54, 321-332 (in Polish).

26. Klimaszyk P., Joniak T., 2008. The impact of forest catchment on the water quality of Lake Piaseczno Small. In: $4^{\text {th }}$ Scientific Conference. ,Active methods of conservation in sustainable forestry. Water for the forest, the forest for water". Rogów, 1-2 April (in Polish).

27. Klimaszyk P., Rzymski P. 2011. The physico-chemical of surface runoff from forest catchments - potential role in forming runoff water quality of small water reservoir. Ochrona Środowiska i Zasobów Naturalnych, 49, 338-344 (in Polish). 